\title{
Expression of the antiviral protein $M x$ in peripheral blood mononuclear cells of pregnant and bred, non-pregnant ewes
}

\author{
S J Yankey ${ }^{1}$, B A Hicks ${ }^{1}$, K G Carnahan ${ }^{1}$, A M Assiri ${ }^{2}$, S J Sinor ${ }^{1}$, \\ K Kodali ${ }^{1}$, J N Stellflug ${ }^{1,3}$ and T L Ott ${ }^{1}$ \\ ${ }^{1}$ Department of Animal and Veterinary Science, University of Idaho, Moscow, Idaho 83844-2330, USA \\ ${ }^{2}$ Department of Animal Sciences, Washington State University, Pullman, Washington 99164, USA \\ ${ }^{3}$ U.S. Sheep Experiment Station, Dubois, Idaho 83423, USA \\ (Requests for offprints should be addressed to T L Ott; Email: tott@uidaho.edu)
}

\begin{abstract}
Interferon-tau (IFN $\tau$ ) acts locally on the endometrium to suppress estrogen and oxytocin receptor expression and block luteolysis in ruminants. Systemic administration of conceptus homogenates or recombinant ovine IFN $\tau$ does not block luteolysis or enhance pregnancy rates in sheep or cattle, respectively. However, IFN $\tau$ up-regulates expression of the antiviral protein $\mathrm{Mx}$ throughout the entire uterine wall during early pregnancy. These studies determined if conceptus-derived IFN $\tau$ also up-regulates $\mathrm{Mx}$ expression in components of the circulating immune system that migrate through the endometrial wall. In experiment one, peripheral blood mononuclear cells (PBMC) were isolated from ewes at D26 post-artificial insemination (AI) and Mx mRNA levels examined by
\end{abstract}

Northern and slot-blot hybridization. Pregnancy resulted in a two-fold increase in Mx mRNA levels compared to bred, non-pregnant ewes at D26. In experiment two, PBMC were isolated from ewes at AI, and every three days from D9 to D30. Results showed a four-fold increase in Mx mRNA levels in PBMC from pregnant versus bred, non-pregnant ewes at D15. Increased Mx mRNA, which remained elevated through D30, was accompanied by increased levels of Mx protein. These results show that pregnancy recognition signaling rapidly induces $\mathrm{Mx}$ gene expression in PBMC, and are the first to suggest that IFN $\tau$ activates gene expression in components of the circulating immune system.

Journal of Endocrinology (2001) 170, R7-R11

\section{Introduction}

Pregnancy recognition in domestic ungulates involves local regulation of endometrial gene expression by the conceptus that results in reduced or altered production of the luteolytic signal, prostaglandin $\mathrm{F}_{2 \alpha}\left(\mathrm{PGF}_{2 \alpha}\right.$; Bazer et al. 1995). This is in contrast to pregnancy recognition in primates, which involves a direct luteotrophic effect on the corpus luteum (CL) by conceptus-produced chorionic gonadotropin (Bazer et al. 1995). Ruminant conceptuses secrete IFN $\tau$, the signal for pregnancy recognition, during the second and third week of pregnancy (Bazer et al. 1995; Godkin et al. 1982). IFN $\tau$ prevents increases in endometrial estrogen and oxytocin receptors, to abrogate oxytocin-induced luteolytic pulses of $\mathrm{PGF}_{2 \alpha}$, and maintains CL function (Spencer et al. 1995).

IFN $\tau$ is a member of the Type I IFN family, which also includes IFN $\alpha, \beta$, and $\omega$ (Samuel 1991). IFN $\tau$ signaling through the Type I IFN receptor and Janus Kinase (JAK)-signal transducer and activator of transcription (STAT) signal transducion pathway (Stewart et al. 2001) induces a number of genes in the ovine uterus including
2',5' oligoadenylate synthetase (Johnson et al. 2001), B2microglobulin (Vallet et al. 1991), IFN regulatory factor 1 (Spencer et al. 1998), ubiquitin cross-reactive protein (Johnson et al. 2000), and Mx protein (Charleston \& Stewart 1993; Ott et al. 1998). While the functions of many of these proteins in the antiviral response are well characterized, their roles during early pregnancy are not.

Mx proteins are monomeric GTPases, which, depending on the species of animal and type of virus are potent inhibitors of viral replication (Samuel 1991). Although the antiviral effects of Mx are generally directed against negative-stranded RNA viruses (e.g. orthormyxovirus), their expression is induced in all cells that possess Type I IFN receptors and is generally predictive of viral infection (Haller et al. 1998). Recently Mx mRNA and protein were shown to be elevated from epithelium (by day 13) to myometrium (by day 15) within the uterine wall in pregnant ewes and levels remained elevated through day 25 (Ott et al. 1998). In addition, Mx mRNA levels were elevated in the corpus luteum in response to injections of roIFN $\tau$ into the uterine lumen (Spencer et al. 1999). 
These results indicated that IFN $\tau$ was either: 1) acting directly on all uterine cell types (i.e., epithelial, stromal and myometrial) and on the CL; or 2) inducing substances (cytokines) that have paracrine/endocrine effects on uterine cells and other organs including the ovaries; or 3) affecting components of the uterine mucosal and circulating immune systems which then affect the various uterine cells and CL. The present studies tested the hypothesis that conceptus-derived IFN $\tau$, expressed during pregnancy recognition signaling, increases $\mathrm{Mx}$ gene expression in PBMC.

\section{Materials and Methods}

\section{Animal models}

For experiment one, 60 mature, white-faced, ewes from the U.S. Sheep Experiment Station (USSES, Dubois ID) were synchronized and bred either by transcervical or laparoscopic AI (AI=D0; Stellflug et al. 2001). At D26, blood $(10 \mathrm{ml})$ was collected by jugular venipuncture into EDTA-containing vaccutainer tubes (Sherwood Medical, St. Louis MO). PBMC were isolated as described below. Pregnancy was determined by assaying serum for pregnancy-specific protein B (PSPB; Biotracking Inc, Moscow ID) and lambing dates and number of lambs born were recorded. In experiment two, 34 mature Suffolk ewes were synchronized and bred by laparoscopic AI. Blood $(20 \mathrm{ml})$ was collected by jugular venipuncture at D0, and every three days from D9 to D30, and PBMC were isolated. Pregnancy was confirmed by real-time ultrasonography and PSPB assay at D30.

\section{PBMC isolation}

Blood was kept on ice until processed. Samples were centrifuged at $300 \mathrm{~g}$ for $20 \mathrm{~min}$ at $4{ }^{\circ} \mathrm{C}$. The buffy coat was removed and resuspended in $0.87 \%$ Tris- $\mathrm{NH}_{4} \mathrm{CL}$ lysis buffer at a 1 to 5 ratio. Samples were incubated for $5 \mathrm{~min}$ at $37^{\circ} \mathrm{C}$ and centrifuged at $300 \mathrm{~g}$ for $10 \mathrm{~min}$. The supernatant was removed and pellets were washed with $10 \mathrm{ml}$ 1X PBS and centrifuged for $10 \mathrm{~min}$ at $300 \mathrm{~g}$. After removal of supernatant, cell pellets were either frozen at $-80{ }^{\circ} \mathrm{C}$ for protein extraction, or lysed with $2 \mathrm{ml}$ TRIZOL (Life Technologies, Grand Island NY) and stored at $-80{ }^{\circ} \mathrm{C}$ for RNA extraction.

\section{RNA extraction, Northern and slot-blot analysis}

Total cellular RNA was extracted using TRIZOL according to manufacture's instructions. RNA was quantified by absorbance at $260 \mathrm{~nm}$. To establish size and number of $\mathrm{Mx}$ transcripts in PBMC, RNA $(5 \mu \mathrm{g})$ was electrophoresed in a $1 \%$ agarose $/ 0 \cdot 615 \mathrm{M}$ formaldehyde gel and transferred to a nylon membrane (Nytran, Schleicher \& Schuell, Keene
$\mathrm{NH})$ by capillary blotting. For quantification of $\mathrm{Mx}$ mRNA levels in PBMC, RNA (5 $\mu \mathrm{g})$ was transferred to a nylon membrane by vacuum filtration (Minifold II, Schleicher \& Schuell, Keene NH). Blots were probed with a biotin-labeled ovine $\mathrm{Mx}$ anti-sense cRNA probe (Ott et al. 1998) using the North2South Hybridization kit (Pierce, Rockford IL) and chemiluminescent signal was quantified using a Bio-Rad Fluor-S Multilmager system and Quantity One software (Bio-Rad, Hercules CA). Slot-blots were stripped and re-probed with an ovine 18s rRNA cRNA probe to correct for variations in RNA loading.

\section{Protein isolation and Western blot analysis}

Total cellular protein was extracted using M-PER reagent (Pierce, Rockford IL), according to manufacturers instructions. Protein concentration of samples was quantified by BCA assay (Pierce, Rockford IL) with bovine serum albumen as the standard. Proteins $(8 \mu \mathrm{g} / \mathrm{sample})$ from PBMC isolated from pregnant and bred, non-pregnant ewes at D15 and D18 were separated by 12\% SDS-PAGE and electrophoretically transferred to a nitrocellulose membrane (BA83, Schleicher \& Schuell, Keene NH). Following blocking of non-specific binding sites in 5\% non-fat dry milk in Tris-buffered saline and Tween 20 (TBST) for $2 \mathrm{~h}$ at $25^{\circ} \mathrm{C}$, membranes were incubated with a 1:1000 dilution of a polyclonal rabbit ovine Mx peptide antiserum (\#90618-2; $0.7 \mu \mathrm{g} / \mathrm{ml}$ ) at $4{ }^{\circ} \mathrm{C}$ overnight. Goat anti-rabbit $\operatorname{IgG}(0.8 \mu \mathrm{g} / \mathrm{ml})$ labeled with horseradish perioxidase was used at a 1:200 000 dilution as secondary antibody. Chemiluminescent signal was developed using the West Femto Maximum Sensitivity Substrate (Pierce, Rockford IL) and quantified using the Fluor-S MultiImager system and Quantity One software.

\section{Analysis}

Chemiluminescent signal was analyzed using GLM procedures of SAS (Version 8.1, SAS Inc, Gary NC). The model included, where appropriate, status (pregnant versus bred, non-pregnant), ewe nested within status, day $(0,9,12,15,18,21,24,27$, and 30) and appropriate interactions. Error terms in the $\mathrm{F}$ test were according to the expectation of mean squares for error. Signal for $18 \mathrm{~s}$ rRNA was run as a covariate in the model to correct for variations in loading. Results are reported as adjusted Least Squares Means (LSM) and pooled standard errors.

\section{Results}

Northern blot analysis (Fig. 1) detected a single, approximately $2.5 \mathrm{~kb}$, band in PBMC isolated from pregnant and 
$\begin{array}{lllllllllllll}1 & 2 & 3 & 4 & 5 & 6 & \text { MW } & 8 & 9 & 10 & 11 & 12 & 13\end{array}$

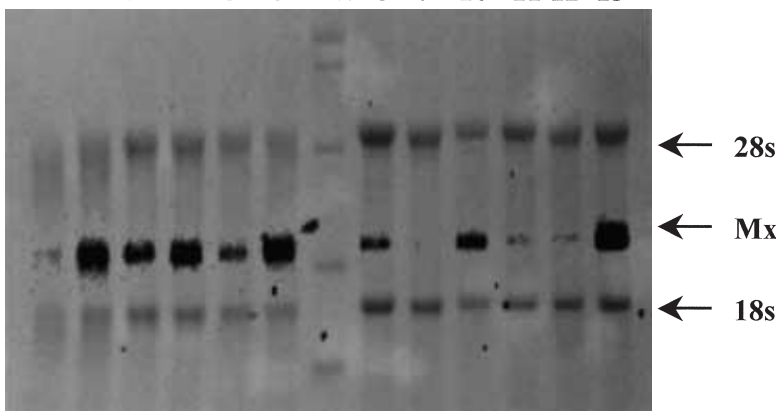

Figure 1 Northern Blot analysis of Mx mRNA from PBMC at D26 post-Al. Lanes 1-6 represent pregnant ewes and lanes 8-13 represent non-pregnant ewes. Mx mRNA migrated at $\sim 2.5 \mathrm{~kb}$.

bred, non-pregnant ewes, which agrees with the known size of the ovine uterine $\mathrm{Mx}$ cDNA (Charleston and Stewart 1993; Ott et al. 1998).

Slot blot analysis (Fig. 2) of total cellular RNA isolated from PBMC collected at D26 post-AI showed a four-fold increase in $\mathrm{Mx}$ mRNA levels in pregnant versus bred, non-pregnant $(n=26)$ ewes $(P<0 \cdot 01)$. In addition, ewes carrying multiples (triplets or quads; $n=10$ ) had higher $\mathrm{Mx}$ mRNA levels than those carrying singles $(n=10)$ or twins $(n=9 ; P<0 \cdot 05)$. Results from the PSPB assay confirmed pregnancy status and, as reported previously, levels of PSPB were correlated with number of lambs born (Willard et al. 1995).

Experiment 2 examined the temporal expression of $\mathrm{Mx}$ mRNA during early pregnancy in sheep (Fig. 3). Results in Fig. 2 are a representative subset of all ewes and depict results from four pregnant and four bred, non-pregnant

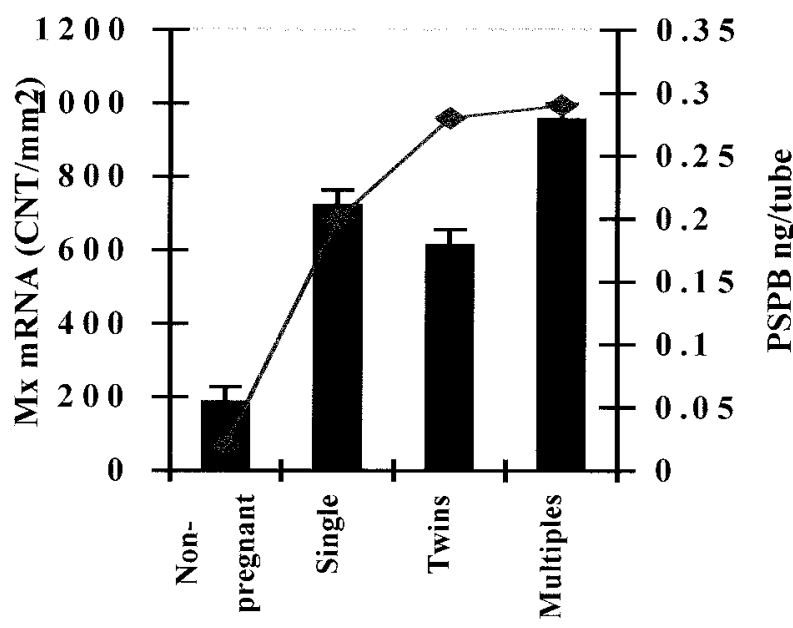

Figure $2 \mathrm{Mx}$ mRNA abundance in PBMC from D26 post-AI. Mx mRNA levels were $\sim 4$ fold greater in pregnant verses bred, non-pregnant ewes at D $26(P<0 \cdot 01)$. PSPB levels (line) confirmed pregnancy status and were correlated with number of lambs born.

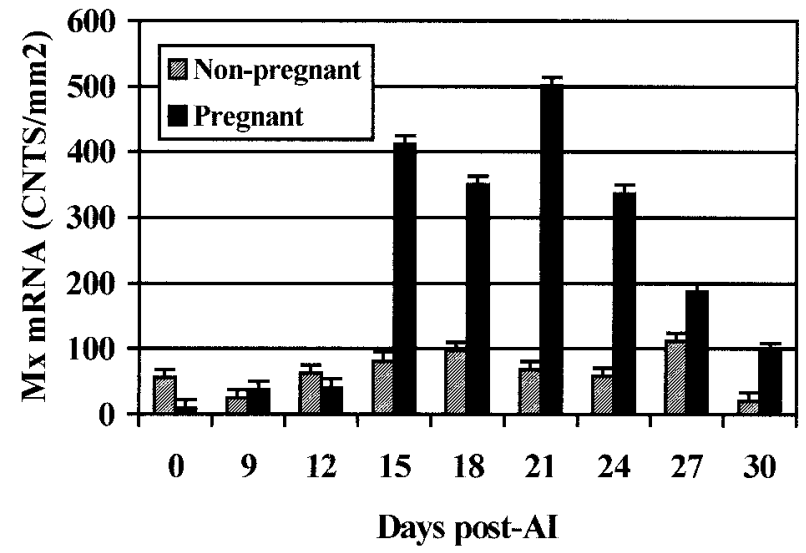

Figure 3 Temporal expression of Mx mRNA in PBMC from D0 to D30 post-AI. Mx mRNA levels were increased in pregnant $(n=4)$ compared with bred, non-pregnant $(n=4)$ ewes beginning at D15 and remained elevated through D30 $(P<0 \cdot 01)$.

ewes during the first 30 days following insemination. This allowed analyzing all replicates on a single blot to eliminate problems associated with signal intensity between blots. Results showed Mx mRNA levels increased in pregnant ewes beginning at D15 $(P<0 \cdot 01)$. Levels peaked at D21 and gradually declined thereafter. At D30, Mx levels in pregnant ewes remained elevated two-fold compared to bred, non-pregnant ewes $(P<0 \cdot 01)$.

$\mathrm{Mx}$ protein expression in PBMC from representative D15 and D18 pregnant and bred, non-pregnant ewes was examined by Western blotting. Mx protein $(\sim 75 \mathrm{kDa})$ was not detected in either D15 or D18 open ewes, but was strongly up-regulated in PBMC from pregnant ewes on both days (Fig. 4). Two additional bands ( $\sim 48$ and $36 \mathrm{kDa})$ were detected in PBMC from pregnant ewes.

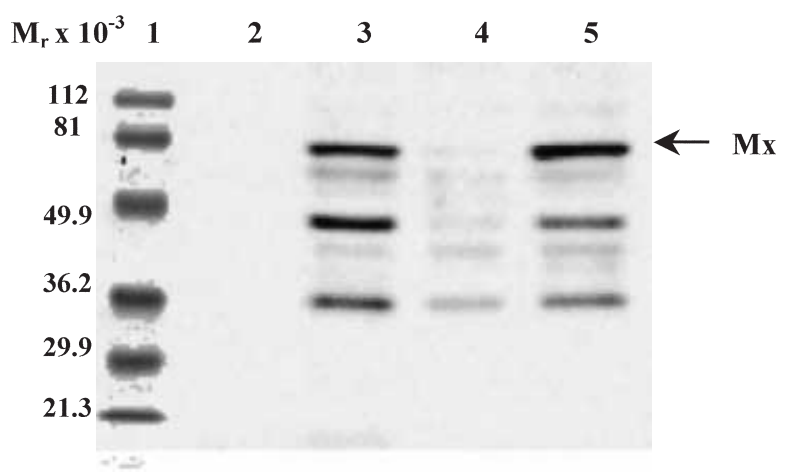

Figure 4 Western blot analysis of Mx protein expression from PBMC at D15 and 18 post-Al. Lanes 2 and 4 represent a bred, non-pregnant ewe at D15 and 18 respectively. Lanes 3 and 5 represent a pregnant ewe at D15 and 18 respectively. Mx protein was up-regulated in PBMC at D15 and 18 of pregnancy. 


\section{Discussion}

Results demonstrate a rapid and sustained activation of $\mathrm{Mx}$ gene expression in PBMC in response to pregnancy recognition signaling, and indicate that, in addition to local effects of IFN $\tau$, there is rapid systemic response in sheep. In addition, $\mathrm{Mx}$ expression did not increase in PBMC when pregnancy was not established (bred, non-pregnant ewes). These findings are novel because pregnancy recognition signaling by IFN $\tau$ was heretofore considered to result solely from local regulation of endometrial gene expression (Stewart et al. 2001; Johnson et al. 2001; Vallet et al. 1991; Spencer et al. 1998; Johnson et al. 2000; Charleston \& Stewart 1993; Ott et al. 1998; Spencer et al. 1999) and suppression of estrogen and oxytocin receptor expression to abrogate luteolytic pulses of $\mathrm{PGF}_{2 \alpha}$ (Spencer et al. 1995). Sheep conceptuses begin to produce high levels of IFN $\tau$ between D12-14 postmating (Bazer et al. 1995). Results from the present study indicate that $\mathrm{Mx}$ gene expression increases 4-5 fold in PBMC within 24-48 h of initial IFN $\tau$ signaling (Bazer et al. 1995). This systemic response to IFN $\tau$ continued through D30 post-AI; 8-10 days after conceptus production of IFN $\tau$ is detectable (Farin et al. 1989). Immunoblotting with $\mathrm{Mx}$ antiserum detected three distinct bands, one of which co-migrated with rhuMxA (supplied by M. Horisberger, Novartis, Basel, Switzerland; not shown). The two lower molecular weight bands may represent multiple Mx genes or partially degraded protein. Although Mx levels were not measured on days 13 or 14 , the magnitude of the increase observed on day 15 suggests that Mx could be detectable in PBMC earlier. Although these studies do not establish if the effect is direct or indirect, we propose that pregnancy recognition signaling involves both local and systemic activation of IFN $\tau$-induced genes.

Recently, Dixit \& Parvizi (2001) demonstrated that bovine pregnancy was accompanied by increased production of adrenocorticotropin and nitric oxide by cultured bovine PBMC. This increase occurred as early as day 7 of pregnancy and levels remained elevated through the first half of gestation. The authors, however, ruled out involvement of IFN $\tau$ in this response. Although the authors did not suggest a mechanism for this increase, they postulated that it occurred as a result of interactions between the immune and endocrine systems at the fetal/maternal interface. Emond et al. (2000) demonstrated in vitro that IFN $\tau$ stimulated granulocyte-macrophage colonystimulating factor gene expression in bovine leukocytes and endometrial stromal cells, independently of its effects on prostaglandin E (PGE) production. This activation remains to be confirmed in vivo. A role for PGE as a luteotropin delivered locally from the uterus to the ovary has long been postulated (Ellinwood et al. 1979), and IFN $\tau$ increased PGE production by bovine endometrial epithelial and stromal cells in vitro (Asselin et al. 1997).
However, a role for PGE in the peripheral circulation during early pregnancy has not been established.

At present, the only known stimuli for Mx expression are Type I IFNs and virus, and its only defined function is in the antiviral response where Mx plays a primary role in blocking replication of negative-stranded RNA viruses (Haller et al. 1998). The simplest explanation for the present results is that $\mathrm{Mx}$ expression is up-regulated in the PBMC of early pregnancy to block potential viral infections; perhaps offsetting the immuno-modulatory actions of progesterone (Gill 1985). Recent results clearly indicate that progesterone interacts with IFN $\tau$ to regulate uterine gene expression (Johnson et al. 2001, Johnson et al. 2000), including the Mx gene (Ott et al. 1999). Whether this is the case for $\mathrm{Mx}$ expression in PBMC remains to be determined. However, the temporal up-regulation of $\mathrm{Mx}$ in the uteri of cyclic ewes, and spatial distribution of $\mathrm{Mx}$ within the uteri of pregnant ewes (Ott et al. 1998), combined with the present results suggest a potential role for Mx outside the response to viral infection.

In summary, these results highlight the rapid communication that occurs between the peri-implantation conceptus and the maternal circulating immune system during pregnancy recognition signaling. Although the function of $\mathrm{Mx}$ in PBMC during early pregnancy remains to be determined, differential Mx expression between PBMC of pregnant and bred, non-pregnant ewes offers an opportunity for early diagnosis of pregnancy loss, which has broad potential application for enhancing reproductive management of domestic ruminants.

\section{Acknowledgements}

The authors thank Dr Greg Johnson for critical review of this manuscript. Supported in part by NIH \#P20 RR15587-01 to TLO. Idaho Agricultural Experiment Station manuscript \#01A02.

\section{References}

Asselin E, Bazer FW \& Fortier MA 1997 Recombinant ovine and bovine interferons tau regulate prostaglandin production and oxytocin resoponse in cultured bovine endometrial cells. Biology of Reproduction $\mathbf{5 6}$ 402-408.

Bazer FW, Spencer TE, Ott TL \& Ing NH 1995 Regulation of endometrial responsiveness to estrogen and progesterone by pregnancy recognition signals during the peri-implantation period. In Molecular and Cellular Aspects of Peri-implantation Processes, pp 27-47. Ed SK Dey. New York: Springer-Verlag.

Charleston B \& Stewart HJ 1993 An interferon-induced Mx protein: cDNA sequence and high-level expression in the endometrium of pregnant sheep. Gene 137 327-331.

Dixit VD \& Parvizi N 2001 Pregnancy stimulates secretion of adrenocorticotropin and nitric oxide from peripheral bovine lymphocytes. Biology of Reproduction 64 242-248.

Ellinwood WE, Nett TM \& Niswender GD 1979 Maintenance of the corpus luteum of early pregnancy in the ewe. II. Prostaglandin 
secretion by the endometrium in vitro and in vivo. Biology of Reproduction 21 845-856.

Emond V, Asselin E, Fortier MA, Murphy BD \& Lambert RD 2000 Interferon-tau stimulates granulocyte-macrophage colonystimulating factor gene expression in bovine lymphocytes and endometrial stromal cells. Biology of Reproduction 62 1728-1737.

Farin CE, Imakawa K \& Roberts RM 1989 In situ localization of mRNA for the interferon, ovine trophoblast protein-1, during early embryonic development of the sheep. Molecular Endocrinology 3 1099-1107.

Gill TJ III 1985 Immunity and pregnancy. Critical Reviews in Immunology 5 201-227.

Godkin JD, Bazer FW, Moffatt J, Sessions F \& Roberts RM 1982 Purification and properties of a major, low molecular weight protein released by the trophoblast of sheep blastocycts at day 13-21. Journal of Reproduction and Fertility 65 141-150.

Haller O, Frese M \& Kochs G 1998 Mx proteins: mediators of innate resistance to RNA viruses. Revue Scientific et Technique 17 220-230.

Johnson GA, Spencer TE, Burghardt RC, Joyce MM \& Bazer FW 2000 Interferon-tau and progesterone regulate ubiquitin crossreactive protein expression in the ovine uterus. Biology of Reproduction 62 622-627.

Johnson GA, Stewart MD, Gray CA, Choi Y, Burghardt RC, Yu-Lee LY, Bazer FW \& Spencer TE 2001 Effects of the estrous cycle, pregnancy, and interferon tau on $2^{\prime}, 5^{\prime}$-oligoadenylate synthetase expression in the ovine uterus. Biology of Reproduction 64 1392-1399.

Ott TL, Yin J, Wiley AA, Kim H, Gerami-Naini B, Spencer TE, Bartol FF, Burghardt RC \& Bazer FW 1998a Effects of the estrous cycle and early pregnancy on uterine expression of $\mathrm{Mx}$ protein in sheep (Ovis aries). Biology of Reproduction 59 784-794.

Ott TL, Gerami-Naini B, Kim H-T, Taylor KM, Spencer TE \& Bazer FW 1999 Expression of the antiviral protein Mx in the ovine uterus is regulated by estrogen $(\mathrm{E})$, progesterone $(\mathrm{P})$, and interferon-

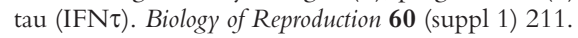

Samuel CE 1991 Antiviral actions of interferons: interferon-regulated cellular proteins and their surprisingly selective antiviral activities. Virology 183 1-11.

Spencer TE, Becker WC, George P, Mirando MA, Ogle TF \& Bazer FW 1995 Ovine interferon-tau inhibits estrogen receptor upregulation and estrogen-induced luteolysis in cyclic ewes. Endocrinology 36 4932-4944.

Spencer TE, Ott TL \& Bazer FW 1998 Expression of interferon regulatory factors one and two in the ovine endometrium: effects of pregnancy and ovine interferon tau. Biology of Reproduction $\mathbf{5 8}$ 1154-1162.

Spencer TE, Stagg AG, Ott TL, Johnson GA, Ramsey WS \& Bazer FW 1999 Differential effects of intrauterine and subcutaneous administration of recombinant ovine interferon tau on the endometrium of cyclic ewes. Biology of Reproduction 61 464-470.

Stellflug JN, Wulster-Radcliffe MC, Hensley EL, Cowardin EA, Seals RC \& Lewis GS 2001 Oxytocin-induced cervical dilation and cervical manipulation in sheep: effects on laparoscopic artificial insemination. Journal of Animal Science 79 568-573.

Stewart MD, Johnson GA, Vyhlidal CA, Burghardt RC, Safe SH, Yu-Lee LY, Bazer FW \& Spencer TE 2001 Interferon tau activates multiple STAT proteins and has complex effects on interferonresponsive gene transcription in ovine endometrial epithelial cells. Endocrinology 142 98-107.

Willard JM, White DR, Wesson CAR, Stellflug J \& Sasser RG 1995 Detection of fetal twins in sheep using a radioimmunoassay for pregnancy-specific protein B. Journal of Animal Science $\mathbf{7 3}$ 960-966.

Vallet JL, Barker PJ, Lamming GE, Skinner N \& Huskisson NS 1991 A low molecular weight endometrial secretory protein which is increased by ovine trophoblast protein-1 is a beta 2-microglobulin-like protein. Journal of Endocinology 130 R1R4. 